\title{
Protein Binding Study of S-Ibuprofen Using High-Performance Frontal Analysis
}

\author{
Longmei Jin, Du Young Choi, Haiyan Liu, and Kyung Ho Row \\ Center for Adranced Bioseperation Technologv and Department of Chemical Engineering.

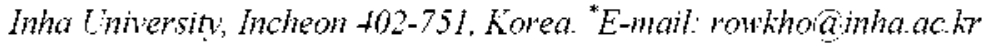 \\ Received October 11, 2004
}

\begin{abstract}
High-performance frontal analysis (HPFA) was used for the determination of the binding constant of Sibuprofen to human serum albumin (HSA). This experiment was based on an Inertsil 100 Diol 5 column and sodium phosphate buffer ( $\mathrm{pH} 7.4$ and ionic strength of 0.17 ) as the mobile phase. The nuisture of S-ibuprofen and HSA $(70 \mu \mathrm{M})$ solution were directly injected into the HPFA column. An injection volume of $200 \mu \mathrm{L}$ and a "restricted injection" method were applied to ensure the drug to be eluted as a zonal peak with a plateau. The unbound drug concentration was calculated from the peak height of the zonal peak. Scatchard analy sis was used for evaluation of the binding constant $(\mathrm{K})$ and binding affinity (nK) of S-ibuprofen to HSA. and the results were $\mathrm{K}=2.833 \times 10^{4}\left[\mathrm{~L} \mathrm{~mol}^{-1}\right], \mathrm{nK}=4.935 \times 10^{-4}\left[\mathrm{~L} \mathrm{~mol}^{-1}\right]$. respectively.
\end{abstract}

Key Words : S-Ibuprofen. HPFA. Binding constant. Protein

\section{Introduction}

The drugs in plasma can cause a reversible and kinetically rapid protein binding process. but their binding characters are different in binding with plasma protein such as albumin.

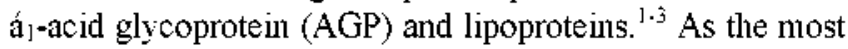
abundant plasma protein, human serum albumin contributes significantly to many transport and regulatory processes. The protein binds a wide variety of substrates like metals. fatty acids, anino acids. homones. and an impressive spectrum of therapeutic drugs. Because of its clinical and pharmaceutical importance. the interaction between serum albumin and a variety of ligands has been studied extensively. ${ }^{4-8}$ The drugs are nore or less bound to plasna protein. and concentration of bound and unbound drugs are in an equilibrium state. Only the unbound drugs can reach the active site and exhibit pharmacological activity. Therefore, determination of the concentration of unbound drug in the plasma is very important for phamacokinetic and pharnacodynanic studies. ${ }^{1 . \hat{3}}$

Several methods have been developed for deternining the concentration of unbound drug. such as equilibrium dialysis. ultrafiltration. ultracentrifugation, gel filtration and microdialysis. ${ }^{9}$ Equilibriun dialysis and ultrafiltration method have been conmonly used because of their relatively simple procedure and device needed. However, these methods have potential problems such as the adsorption of drug onto membranes and the leakage of bound drug through membranes. In addition. the equilibrium between bound and unbound drug night shift during the experinent due to a volume shift. ${ }^{1 j}$ Binding analysis using a separation system such as HPLC and capillary electrophoresis has the potential to avoid these problents, and several analytical modes have been proposed. ${ }^{11,12}$ Recently. high-performance frontal analysis (HPFA) had been developed and demonstrated as an alternate chromatographic method suitable for the analysis of strong binding properties of protein because the bound drug is transformed into unbound form in the columm, which improves the measurement of low levels of unbound drug. ${ }^{10}$ It can be free from the protein leakage and drug absorption existed in the conventional ultrafiltration and dialysis method for its gel filtration mechanism.

In case of racemic drug. the binding affinity may be different between the enantiomers. which may cause the difference in their phamnacokinetic properties. ${ }^{13.17}$ The enantiomer-enantioner interaction may also affect the binding equilibrium of both enantiomers. Therefore. quantitative and enantioselective binding study of the enantiomers to proteins is important for developing a stereoselective drug and its safe and rational use. ${ }^{15}$

The ibuprofen $(r c c-1)$ is an arylpropionic acid related to the class of non-steroidal, anti-inflammatory drugs. ${ }^{16}$ It was shown that only the (S)-enantiomer is responsible for the desired therapeutic effects. ${ }^{17}$ while the $(R)$-ibuprofen displays toxicity due to its storage in fatty tissue as a glycerol ester, whose long-term effects are not known: ${ }^{18}$ despite this fact, the ibuprofen is currently administered as racemate. The binding study of S-ibuprofen to HSA was applied with other method. ${ }^{19}$ In this paper, the HPFA method was used for the binding assay of S-ibuprofen to HSA.

We performed experiments with low concentration of HSA. This result could produce important information for the clinical use of this drug.

\section{Experimental Section}

Materials. S-Ibuprofen. Human Serum Albumin (HSA, essentially fatty acid and globulin free), sodium phosphate monobasic dilydrate $\left(\mathrm{NaH}_{2} \mathrm{PO}_{4} \cdot 2 \mathrm{H}_{2} \mathrm{O}\right)$ and sodium phosphate dibasic heptalyydrate $\left(\mathrm{Na}_{2} \mathrm{HPO}_{4} \cdot 7 \mathrm{H}_{2} \mathrm{O}\right)$ were purchased from Sigma (St. Louis, MO, USA). The diol-silica column (Inertsil 100 Diol 5, $100 \times 4.6 \mathrm{~mm}$ ) was purchased from GL Sciences Inc. (Japan). Water was twice distilled and filtered by using decompressing pump (Division of Millipore. 
<smiles>CC(C)Cc1ccc(C(C)C(=O)O)cc1</smiles>

Figure 1. Chemical structure of S-ibuprofen.

Waters) and filter ( $\mathrm{F}-0.45, \mu \mathrm{m})$.

Instruments. The instruments used in this study were as follows: M930 solvent delivery pump (Young Lin Co.), UV detector (M 720 Absorbance Detector, Young-In Scientific Co.), column oven (CTS30 HI'LC Column Oven, Young Lin Co.), a Rheodyne injection valve with a I $\mathrm{mL}$ sample loop. and integrated data system (Autochrowin. Ver. I.42, Young Lin Co.).

Preparation of Sample Solutions. First, sodium phosphate monobasic dihydrate $\left(\mathrm{NaH}_{2} \mathrm{PO}_{4} \cdot 2 \mathrm{H}_{2} \mathrm{O}\right)$ and sodium phosphate dibasic heptahydrate $\left(\mathrm{Na}_{2} \mathrm{HPO}_{4} \cdot 7 \mathrm{H}_{2} \mathrm{O}\right)$ were dissolved in water to make solutions of $0.2 \mathrm{M}$, respectively. Then the two solutions were mixed together $(19 \%$ $\mathrm{NaH}_{2} \mathrm{PO}_{4} \cdot 2 \mathrm{H}_{2} \mathrm{O}$ and $81 \% \mathrm{Na}_{2} \mathrm{HPO}_{4} \cdot 7 \mathrm{H}_{2} \mathrm{O}$ ). By this way, phosphate solution of $\mathrm{pH} 7.4$, ionic strength 0.17 was made and it was used as the mobile phase in HPFA analysis. Slbuprofen $(120 \mu \mathrm{M})$ and HSA solution $(140 \mu \mathrm{M})$ was prepared by dissolving the samples into phosphate solution. Sample solutions were kept at $37^{\circ} \mathrm{C}$ in a column oven for 3 $\mathrm{h}$ before being injected into the HPFA column.

\section{Results and Discussions}

Determining the Injection Volume. After incubation at $37^{\circ} \mathrm{C}$ for $3 \mathrm{~h}$, The S-ibuprofen-HSA mixed solution was directly injected into the HPFA column. According to the principle of HPFA. the drug should be eluted as a zonal peak with a plateau after the non-retained HSA. Hence a restricted injection method called as "injection-re-switching technique" was used. The procedure was as follows: the injection loop was loaded with a certain volume (it must be

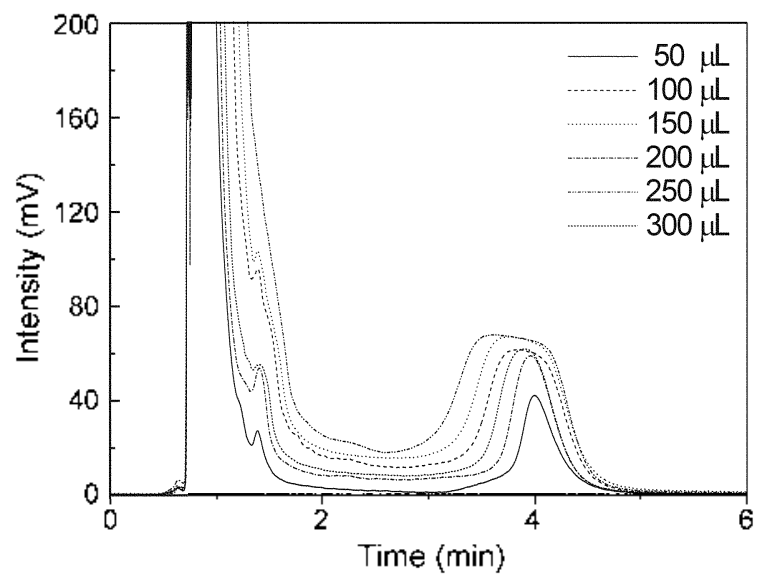

Figure 2. The effect of injection volumes on the elution protiles of $60 \mu \mathrm{M} \mathrm{S}$-ibuprofen and $70 \mu \mathrm{M}$ HS $\wedge$ mixed solution. Mobile phase: sodium phosphate bulter $(p \mathrm{I}=7.4 . \mathrm{I}=0.17$ ). I low rale. I $\mathrm{mL} / \mathrm{min}$. UV wavelength $220 \mathrm{~nm}$. Temp. $37^{\circ} \mathrm{C}$.

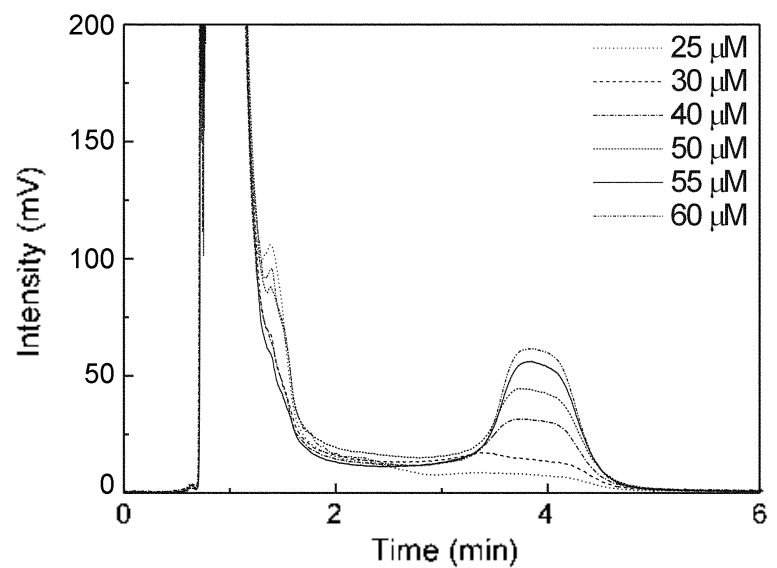

Figure 3. Chromatograms of S-ibuprofen with different concentrations in $70, U \mathrm{M}$ IISA by IIPHA

larger than actual injection volume) of the sample solution and connected with mobile phase for a certain period. Then the injector valve was re-switched, which resulted in a sample injection of desired volume, then the loop was detached from mobile phase flow. By this injection reswitching technique, the diffused portion of the sample in the injection loop was not introduced into column and the injection could be regarded as an ideal rectangular. Figure 2 shows the elution profiles of $70 \mu \mathrm{M} \mathrm{HSA}$ and $60 \mu \mathrm{M} \mathrm{S}$ ibuprofen mixed solution with different injection volume. It can be seen when injection volume was in the range from 50 $\mu \mathrm{L}$, to $150 \mu \mathrm{L}$. S-ibuprofen was eluted as a normal gaussian peak. Injections above $200 \mu \mathrm{L}$, result in trapezoidal peak with a plateau region. The height of the plateau region corresponds to the unbound drug concentration in the sample solution. Based on this result, the injection volume of this analysis was fixed at $200 \mu \mathrm{L}$, for further experiment.

Determination of Unbound S-Ibuprofen by HPFA/ HPLC system. Different concentrations of S-ibuprofen changing from $25 \mu \mathrm{M}$ to $60 \mu \mathrm{M}$ with the HSA concentration maintained at $70 \mu \mathrm{M}$ were injected to the HPFA system. From the heights of the peak plateaus, the unbound drugs could be determined (see Fig. 3). For quantitative determinations, calibration was carried out under the same condition as that in HPFA. Standard S-ibuprofen samples in the absence of HSA were directly injected into the column with the injection volume of $200 \mu \mathrm{L}$. By plotting of peak height vs concentrations, the regression equation of the calibration

Table 1. Determination of unbound drugs of S-ibuprolen by IIPI'A

\begin{tabular}{ccc}
\hline $\begin{array}{c}\text { lotal Concentration } \\
{[\mu \mathrm{M}]}\end{array}$ & $\begin{array}{c}\text { Inbound drug } \\
{[\mu \mathrm{M}]}\end{array}$ & $\begin{array}{c}\text { Bound drug } \\
{[\mu \mathrm{M}]}\end{array}$ \\
\hline 25 & 6.319 & 18.681 \\
30 & 7.877 & 22.123 \\
40 & 11.076 & 28.924 \\
50 & 14.471 & 35.529 \\
55 & 16.456 & 38.544 \\
60 & 18.199 & 41.800 \\
\hline
\end{tabular}

Concentration of HSA was lixed to $70 \mu \mathrm{M}$ 


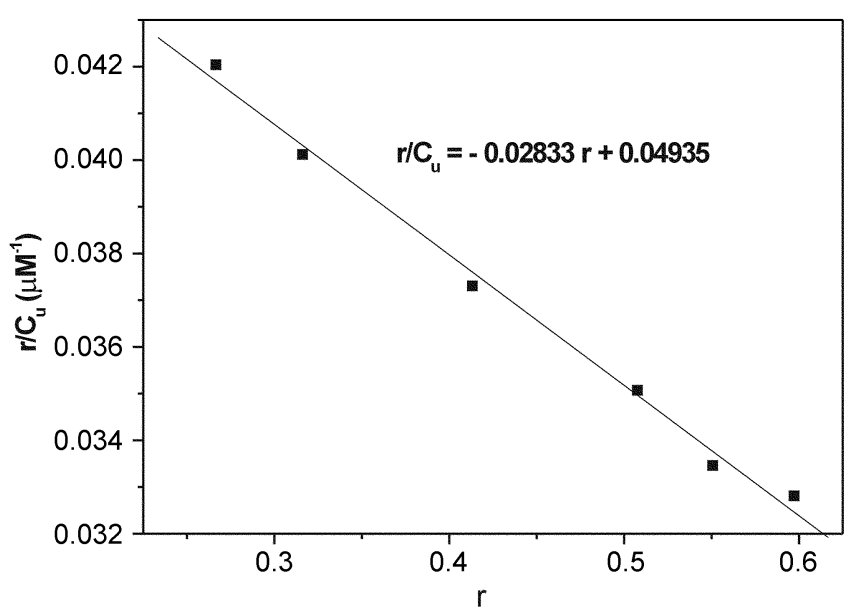

Figure 4. The Scatchard plot for S-ibuprofen-HSA binding. The correlation coeflicient of the line was 0.9956 .

curve was $y=0.2202 x+4.3474$ and correlation coefficient $\left(\mathrm{r}^{2}\right)$ was obtained 0.9941 for $\mathrm{S}$-ibuprofen. The determined unbound drugs for the S-ibuprofen are listed in Table I. It can be seen from Table 1 that in the equilibria of HSA and Sibuprofen, the unbound drug is about $25 \%-30 \%$ in the investigated concentration range, which contributes to the parts that can easily transfer from blood into the target organ to exert the pharmaceutical activity for $\$$-ibuprofen.

Determination of Binding Parameters. The binding parameters were determined by fitting the experimental data to the Scatchard equation ${ }^{16}$;

$$
\mathrm{r} / \mathrm{Cu}--\mathrm{Kr}+\mathrm{nK}
$$

Where $\mathrm{r}, \mathrm{Cu}, \mathrm{K}$ and $\mathrm{n}$ represent the number of moles of bound drug per mole of HSA protein, the unbound drug concentration, the binding constant, and the number of binding sites on one HSA molecule, respectively.

rigure 4 illustrates the Scatchard plots of S-ibuprofen. The correlation coefficient $\left(r^{2}\right)$ of the line was 0.9956 , which indicates a good agreement of the experimental data to the theoretical equation. From the slope and intercept of the Scatchard plots, the calculated binding parameters of Sibuprofen are: $\mathrm{K}=2.833 \times 10^{4}\left(\mathrm{~L} \mathrm{~mol}^{-1}\right), \mathrm{nK}=4.9353 \times 10^{4}$ $\left(\mathrm{L} \mathrm{mol}{ }^{-1}\right)$.

\section{Conclusions}

A IJPFA method has been successfully applied for the protein binding study of S-ibuprofen to human serum albumin. This method is simple and precise and can be used for the quantitative binding determination of the S-ibuprofen and HSA mixed solution. In this paper, the binding study of S-ibuprofen to HSA using HPFA method has been applied. From the peak height of the zonal peak, the unbound drug concentration was calculated. By Scatchard analysis, the binding constant $(\mathrm{K})$ and binding affinity $(\mathrm{nK})$ of Sibuprofen were $2.833 \times 10^{4}\left[1, \mathrm{~mol}^{-1}\right]$ and $4.935 \times 10^{4}$ $\left[1\right.$. mol $\left.^{-1}\right]$, respectively. This work may provide useful information for clinical application of this drug.

Acknowledgment. The authors were grateful for the financial support of the Center for Advanced Bioseparation Technology.

\section{References}

1. Meycr. M. Gi: Guttman. D. E. J. Pham. Sei. 1968. 57.895.

2. Kwong. T. C. Clin. Chim Acta 1985. /5/.193.

3. Svensson. C. K.: Woodrult: M. N.: Baver. J. Ci: I alka D. ( Tim. Pharmacokinet 1986. He 450

4. Fehske. K. J.: Müller. W. E.: Wollentl. U. Mol. Pharmacol 1979. 16. 778 .

5. Sjöholm. I.: Erınan. B.: Kober. A.: Ljungstedt-Pahlman. I.: Sciving B.: Sjödin. T. H/. Pharmacol 1979. 16.767.

6. Kragly-l lamsen. (J. Wol Phtmotcol. 1988. 3t. 160.

7. Davila. I. I larriman. A.J. Am. (hem. Soc 1990. /12.2686

8. Rotenberg. M.: Cohen. S.: Margalit. R. Photochem. Photohiol. 1987. 46.689

9. Lit. Z.: Li. F.: Huang. Y. Biomed. Chromatogr: 1999. 13. 262.

10. Qias. M.: Guo. X.: I.i. F. J. Chromatogr .1 2002, 952, 131.

11. Oravcova. J. 13ohs. B.: lindner. W. J. Chomatogr: 1996. 677 .

12. Hage. D. S.: Austin. J. /. (homatogr: B 2000. 739. 39.

13. Noctor. T. In Drig Stereochemistry: $2^{\text {nd }}$ cd: Wainer I. W.. Ed.: Dekker: New York. 1993: Chapter 12.

14. Tucker. (. T.: I ennard, M, S. Phamacol. Ther 1990. 45.309.

15. Shibukawa A.: Yoshikawa Y: Kimura T: Kuroda. Y.: Nakkagawa. T.: Wainer. I. W.J. (hmomatogr: B 20112, 768. 189.

16. Lombardino. G I. Aon-steroidal Anti-inflammatory Drngs: Wiley Interscience: Nicw York. 1985.

17. Adams. S. S.: Bresloff. P.: Mason. C. G J. Pham. Pharnacol. 1976, 28,256 .

18. Willams. K.: Day. R.: Knihinicki. R.: Iuflield. A. Biochem. Phameteol. 1986. 35. 3403 .

19. Ammazcaloso. A.: Amoroso. R.: Bettoni. G: Filippis. B. D.: Giampictro. L.: Picrini. M.: Tricea. M. L. Tetrotedron Letters 2002. 43,4325 .

20. Itoh, T.: Saluris Y: Tsuda Y: Yamada II, Chirality 1997, 9. 643 